\title{
The Three Tier-Test untuk Mengungkap Kuantitas Siswa Yang Miskonsepsi Pada Konsep Gaya Pegas
}

\author{
Septi Maulini ${ }^{1)}$, Yudi Kurniawan ${ }^{2}$, Riski Muliyani ${ }^{3)}$ \\ 1) Prodi Pendidikan Fisika STKIP Singkawang \\ E-mail: septisepti876@gmail.com \\ ${ }^{2)}$ Prodi Pendidikan Fisika STKIP Singkawang \\ E-mail: yudikurniawan1012@gmail.com \\ ${ }^{3)}$ Prodi Pendidikan Fisika STKIP Singkawang \\ E-mail: kikiriski1012@gmail.com
}

\begin{abstract}
Abstrak. Sebelum memasuki ruang pembelajaran para siswa telah memiliki konsep masing-masing mengenai fisika. Konsep tersebut berasal dari interaksi siswa dengan lingkungan. Konsep awal yang dimiliki siswa tersebut sering kali mengalami miskonsepsi atau tidak cocok dengan konsep yang dimiliki oleh fisikawan.Faktor lain yang menyebabkan siswa mengalami miskonsepsi adalah proses pembelajaran yang dilakukan masih berfokus pada hafalan dan rumus sehingga pada saat siswa diberikan bentuk soal mengenai penguasaan konsep, siswa mengalami kesulitan. Berhasil atau tidaknya siswa dalam mempelajari fisika sangat ditentukan oleh penguasaan konsep yang dimiliki. Penguasaan konsep yang kurang dapat menyebabkan siswa mengalami miskonsepsi. Miskonsepsi adalah suatu konsep yang tidak sesuai atau konsep yang salah dengan pengertian ilmiah dengan para ahli. Konsep yang salah atau tidak sesuai yaitu konsep yang bertentangan dengan konsepsi para fisikawan.Penelitian ini bertujuan untuk mendapatkan gambaran mengenai kuantitas siswa yang miskonsepsi pada konsep gaya pegas. Penelitian ini adalah deskriptif kuantitatif dengan teknik purposive sampling. Siswa diwajibkan untuk menjawab soal (dalam bentuk three tier-test) tentang konsep gaya pegas pada lembar jawaban, kemudian lembar jawaban siswa dianalisis. Terdapat dua sub konsep distribusi miskonsepsi pada materi Gaya Pegas yaitu; 1. Pada susunan pegas seri gaya terbesar terjadi pada pegas yang dekat dengan beban; 2. Gaya yang bekerja pada masing-masing pegas paralel sama dengan gaya yang diberikan dimana $\vec{F}=\vec{F}_{1}=\vec{F}_{2}$. Hasilnya menunjukkan bahwa persentase kuantitas siswa yang miskonsepsi yang terjadi pada kedua konsep adalah sama. Dengan adanya penelitian ini diharapkan pada penelitian selanjutnya dapat memberikan solusi untuk mereduksi kuantitas siswa yang miskonsepsi pada materi gaya pegas.
\end{abstract}

Kata Kunci: Three Tier-Test, Kuantitas Siswa yang Miskonsepsi, Gaya Pegas.

\section{PENDAHULUAN}

Ilmu Pengetahuan Alam (IPA) berkaitan dengan cara mencari tahu tentang fenomena alam secara sistematis, sehingga IPA bukan hanya penguasaan kumpulan pengetahuan dan hasil (produk) saja akan tetapi juga merupakan suatu proses penemuan. Pendidikan IPA diarahkan untuk mencari tahu dan berbuat sehingga dapat membantu siswa untuk memperoleh pemahaman yang lebih mendalam tentang alam sekitar (Permendiknas, 2006: 113). Untuk dapat memahami fisika secara luas, maka harus dimulai dengan kemampuan penguasaan konsep dasar pada pelajaran fisika. Berhasil atau tidaknya seorang siswa dalam memahami tentang pelajaran fisika sangat ditentukan oleh penguasaan konsep.

Sebelum siswa mengikuti pelajaran yang dibimbing guru, siswa tentu lebih dahulu memiliki konsepsi awal atau prakonsepsi. Namun, dari konsepsi awal tersebut, terdapat sebagian yang mengandung miskonsepsi atau kesalahan konsep. Biasanya prakonsepsi ini diperoleh dari orang tua, teman, sekolah awal, dan pengalaman di lingkungan siswa. Hal ini disebabkan pengetahuan awal tersebut diperoleh dari pengalaman yang berbeda-beda dan sumber informasi yang tidak akurat, padahal penguasaan pengetahuan awal yang dimiliki seseorang sangat berpengaruh terhadap perolehan pengetahuan di sekolah [1]. Miskonsepsi 


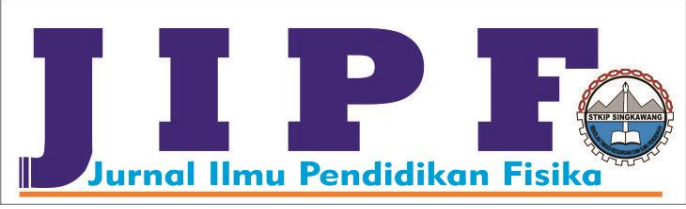

atau kesalahan konsepsi merupakan konsepsi awal siswa yang terkadang tidak sesuai atau bertentangan dengan konsepsi yang diterima para ahli. Jenis miskonsepsi yang paling sering terjadi adalah bukan pengertian yang salah selama proses pembelajaran melainkan suatu konsepsi awal (prakonsepsi) yang dibawa siswa selama proses pembelajaran [2].

Untuk mengungkap kuantitas siswa yang miskonsepsi pada penelitian ini menggunakan three tier-test . TTT (Three Tier-Test) adalah salah satu jenis tes diagnostik yang menggunakan identifikasi miskonsepsi dan pemahaman konsep siswa [3]. TTTmemiliki tiga tingkatan, pertama adalah menanyakan pengetahuan siswa tentang konsep dari pilihan ganda. Tingkatan kedua adalah penalaran siswa dari proses menjawab pada tingkatan pertama. Tingkatan ketiga adalah pertanyaan mengenai keyakinan siswa tentang jawaban tingkatan pertama dan kedua.

Pada penelitian ini penulis akan mengungkap kuantitas siswa yang miskonsepsi. Diharapkan pada penelitian selanjutnya dapat memberikan solusi untuk mereduksi kuantitas siswa yang miskonsepsi pada materi gaya pegas.

\section{METODE}

Jenis penelitian yang digunakan pada penelitian ini adalah deskriptif kuantitatif dan hasil dari penelitian ini adalah gambaran mengenai jumlah kuantitas siswa yang miskonsepsi pada materi konsep gaya pegas.

Populasi dalam penelitian ini adalah siswa kelas XI di salah satu SMA Negeri di Singkawang. Teknik pengambilan sampel dalam penelitian ini adalah purposive sampling dengan melibatkan seluruh siswa kelas XI IPA yang berjumlah 20 orang.

Penggunaan TTT dapat mempermudah dalam mengungkapkan miskonsepsi yang terjadi pada siswa. Adapun analisis untuk menentukan miskonsepsi diberikan pada Tabel 1 berikut [4].
Jurnal Ilmu Pendidikan Fisika

Volum 1 Nomor 2 September 2016. Halaman 42-44 p-ISSN: 2477-5959 e-ISSN: 2477-8451

TABEL 1

KEPUTUSAN DARI THREE TIER-TEST

\begin{tabular}{cccc}
\hline $\begin{array}{c}\text { Tingkatan } \\
\mathbf{1}\end{array}$ & Tingkatan $\mathbf{2}$ & Tingkatan 3 & Keputusan \\
\hline Benar & Benar & Yakin & Konsepsi Ilmiah \\
Benar & Salah & Yakin & Miskonsepsi \\
Salah & Salah & Yakin & Miskonsepsi \\
Salah & Benar & Yakin & Miskonsepsi \\
Benar & Salah & Tidak Yakin & Menebak \\
Salah & Benar & Tidak Yakin & Menebak \\
Benar & Benar & Tidak Yakin & Lucky Guess \\
Salah & Salah & Tidak Yakin & Lack of \\
& & & Knowledge \\
\hline
\end{tabular}

Bentuk miskonsepsi yang dialami oleh siswa yang terdiri dari dua konsep pada konsep gaya pegas yang ditampilkan pada Tabel 2 berikut.

TABEL 2

BENTUK MISKONSEPSI PADA KONSEP GAYA PEGAS

\begin{tabular}{cl}
\hline No. Konsep & \multicolumn{1}{c}{ Miskonsepsi } \\
\hline 1 & $\begin{array}{l}\text { Pada susunan pegas seri, gaya terbesar terjadi } \\
\text { pada pegas yang dekat dengan beban }\end{array}$ \\
& $\begin{array}{l}\text { Gaya yang bekerja pada masing-masing pegas } \\
\text { paralel sama dengan gaya yang diberikan dimana }\end{array}$ \\
& $\vec{F}=\vec{F}_{1}=\vec{F}_{2}$ \\
\hline
\end{tabular}

\section{HASIL DAN PEMBAHASAN}

Berdasarkan tes diagnostik, secara garis besar profil kuantitas siswa miskonsepsi disajikan dalam bentuk diagram berikut.

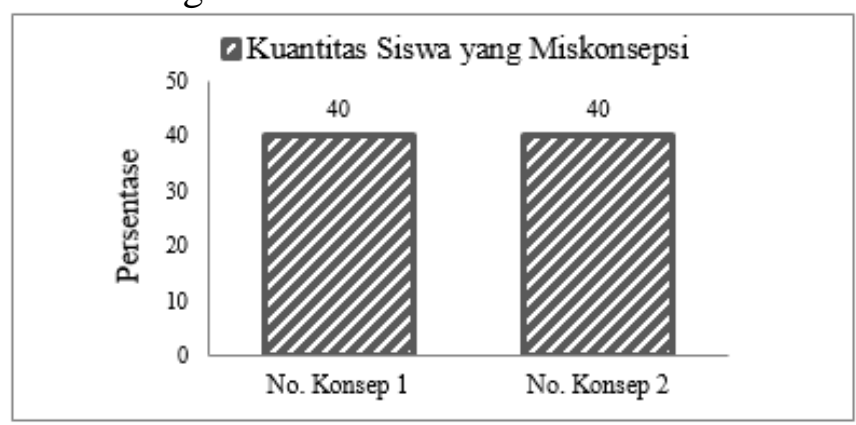

Gambar 1. Persentase Kuantitas Siswa yang Miskonsepsi

Penelitian ini adalah untuk mengungkap adanya miskonsepsi pada siswa dengan three tier-test tentang konsep gaya pegas. Berdasarkan Gambar 1, persentase kuantitas siswa yang miskonsepsi No. Konsep 1 yaitu "pada susunan pegas seri, gaya terbesar terjadi pada pegas yang dekat dengan beban" adalah sebesar 40\% sedangkan konsepsi ilmiah adalah "gaya yang bekerja pada masingmasing pegas yang disusun seri besarnya sama 


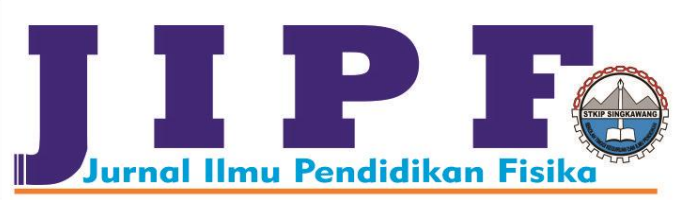

dengan gaya yang diberikan"dan No. Konsep 2 yaitu "gaya yang bekerja pada masing-masing pegas paralel sama dengan gaya yang diberikan dimana $\vec{F}=\vec{F}_{1}=\vec{F}_{2}$ " adalah sebesar $40 \%$, pada bentuk miskonsepsi ini siswa sering menganggap bahwa gaya pada masing-masing pegas yang disusun secara paralel adalah sama dengan mengabaikan nilai dari masing-masing konstanta pegas, namun menurut konsepsi ilmiah adalah "gaya yang bekerja pada masing-masing pegas yang disusun paralel besarnya berbeda, bergantung pada nilai konstanta gaya pegasnya dimana $\vec{F}=$ $\vec{F}_{1}+\vec{F}_{2}$ ” jika konstanta dari salah satu pegas tersebut lebih besar dari pegas yang lain maka gaya yang diperlukan juga semakin besar.

Masih terdapat miskonsepsi yang dimiliki siswa pada konsep gaya pegas ini dikarenakan pengetahuan yang didapat siswa pada kehidupan sehari-hari tidak dapat dibuktikan secara ilmiah. Selain itu, hal yang dapat menyebabkan terjadinya miskonsepsi ialah penyusunan pengetahuan dilakukan berdasarkan informasi yang diperoleh dari pengalaman nyata yang berhubungan dengan kehidupan sehari-hari siswa, jika siswa salah menyusun pengetahuannya, siswa akan mengalami kesalahan pemahaman dalam menghubungkan antar konsep [5].
Jurnal Ilmu Pendidikan Fisika

Volum 1 Nomor 2 September 2016. Halaman 42-44 p-ISSN: 2477-5959 e-ISSN: 2477-8451

\section{KESIMPULAN DAN SARAN}

\section{A. Simpulan}

Berdasarkan dari hasil analisis data yang dilakukan miskonsepsi pada konsep gaya pegas terdapat 2 bentuk miskonsepsi, dengan persentase yang sama yaitu sebesar $40 \%$.

B. Saran

Diharapkan pada penelitian selanjutnya dapat memberikan solusi untuk mereduksi kuantitas siswa yang miskonsepsi agar kedepannya tidak terjadi kembali bentuk miskonsepsi yang serupa.

\section{DAFTAR PUSTAKA}

[1] Wahyuningsih, Tri., Raharjo, Trustho., Masithoh, Dyah Fitriana. (2013). "Pembuatan Instrumen Tes Diagnostik Fisika SMA Kelas XI". Jurnal Pendidikan Fisika (2013) 1 (1), 111-117.

[2] Suparno, Paul. (2005). Miskonsepsi dan Perubahan Konsep dalam Pendidikan Fisika. Jakarta: Grasindo.

[3] Muliyani, Riski. \& Kaniawati, Ida. (2015). "Identification of Quantity Students' Misconceptions on Hydrostatic Pressure with Three TierTest”. Global Iluminators Publishing, (2), 716-721.

[4] Kurniawan, Yudi. \& Suhandi, Andi. (2015)."The Three Tier-Test for Identification The Quantity of Students' Misconception on Newton's First Laws". Global Iluminators Publishing, (2), 313-319.

[5] Isnaini. (2015). "Identifikasi Miskonsepsi Mahasiswa Fisika Menggunakan Tes Diagnostik Pada Mata Kuliah Fisika Dasar Materi Gaya Dan Gerak". KONSTAN: Jurnal Fisika dan Pendidikan Fisika Vol. 1. no.1 (2015) hal. 29-3. 